\title{
Food and Environmental Virology
}

September 2010, Volume 2, Number 3, 115-116

http://dx.doi.org/10.1007/s12560-010-9046-1

(c) 2010 Springer, Part of Springer Science+Business Media

The original publication is available at http://www.springerlink.com

\section{Introduction : Viruses in Shellfish}

\author{
Albert Bosch ${ }^{1, *}$ and Soizick F. Le Guyader ${ }^{2, *}$
}

\footnotetext{
${ }^{1}$ Univ Barcelona, Dept Microbiol, E-08028 Barcelona, Spain

2 IFREMER, Microbiol Lab, F-44311 Nantes 03, France *: Corresponding author : Soizick F. Le Guyader, email address : Soizick.Le.Guyader@ifremer.fr, Albert Bosch,
email address : $\underline{\text { abosch@ub.edu }}$
} 


\section{INTRODUCTION}

Human pathogenic viruses enter the marine environment through several routes which include direct discharge of treated or untreated sewage effluents, unintentional discharges by urban and rural run-off, waste input from boats, and via rivers when wastewater discharges take place in fresh water. Current water treatment practices are unable to provide virus-free wastewater effluents, consequently human pathogenic viruses are routinely introduced into marine and estuarine waters. During feeding and under favorable hydrographic conditions, molluscan bivalves filter contaminants from polluted water and accumulate them within their edible tissues. A major public health concern posed by virus contaminated bivalves is that shellfish are often eaten raw, like oysters and clams, or improperly cooked, like most of other molluscan shellfish, just steamed for a few minutes.

Although environmental virology started with the detection of poliovirus in water, other enteric viruses responsible for gastroenteritis and hepatitis have replaced enteroviruses as the main target for detection in the environment. Most shellfishborne viral outbreaks are restricted to norovirus and hepatitis A virus making them the main targets for bivalve virological analysis. In the present issue, updated extensive information on the state of the art noroviruses and hepatitis A virus is provided in the first two papers.

According the information provided by different outbreaks, the most common route for transmission is accidental contamination after heavy rainfall, when extra loads cause an overflow and release of untreated sewage into the aquatic environment. The environmental conditions leading to shellfish consumption related outbreaks are described in a paper in the present issue.

The inclusion of virus analysis in regulatory standards for viruses in molluscan bivalve samples must overcome several shortcomings such as the technical difficulties and high costs of virus monitoring, the lack of harmonized and standardized assays and the challenge posed by the ever changing nature of viruses. Nowadays methods are available to detect, quantify and characterize viral pathogens in molluscan shellfish to reduce the risks of shellfishborne virus diseases. However, standardization is necessary before virus methods can be considered for adoption within a regulatory framework. A European standardisation working group is developing a two-part (quantitative and qualitative) standard method for virus detection in foodstuffs including shellfish which has the potential to be incorporated into EU legislation as a reference method. This development is described in another paper.

Important trade exchanges of shellfish take place worldwide. Most countries have endorsed sanitary controls on live bivalve shellfish. In this issue, human enteric virus occurrence in shellfish from European markets is covered in one study after consulting different sources. The data demonstrate that viral RNA can be detected in shellfish from polluted areas, in depurated 
shellfish as well as in those for human consumption, without a good relation with the E. coli MPN that is in use for classification of growing areas and to determine whether shellfish products can be presented for human consumption.

The reference guidelines, regulatory programs and management practices to manage both recreationally and commercially grown shellfish developed in New Zealand are discussed in another contribution. These measures help to ensure the safety and quality of shellfish for public consumption both on the domestic and international markets and so reduce the risk of illness.

Also covered in this issue is a study aimed to determine the seasonal and geographical distribution of noroviruses and hepatitis A virus in live U. S. market oysters. The conclusion of the study is that the seasonal occurrence of viruses corresponded to the reported incidence of shellfish- associated viral illnesses.

The final paper in this special issue reviews the state-of-the-art in food processing strategies for the inactivation of enteric viruses in shellfish. Several methods can improve shellfish safety; however, from a commercial standpoint, none of the methods can guarantee total virus inactivation without impacting the organoleptic qualities of the shellfish.

Bivalve mollusc consumption may be regarded as a two-faced issue, on the one hand as a delicious and sensual food providing nutrient and easy to grow food, and on the other, a matter of concern since shellfish is a common cause for infections such as gastroenteritis or hepatitis, with transnational outbreaks reported with increasing frequency as a consequence of the global food trade. This special issue of Food and Environmental Virology provides cutting edge overviews and updates on the present status of research, diagnosis, epidemiology, and intervention to prevent shellfishborne virus transmission. Shellfish ought to be protected as it an indication of coastal water quality, and this represent an important challenge for the following years. 